\title{
FAKTOR YANG MEMPENGARUHI PERILAKU IBU DI KELURAHAN WONOKUSUMO UNTUK MELAKUKAN ANTENATAL CARE
}

\author{
FACTORS AFFECTING THE MOTHER BEHAVIOR IN THE WONOKUSUMO VILLAGE \\ TO ANTENATAL CARE
}

\author{
Lina Agustin Kusumawardhani ${ }^{1)}$, Shrimarti Rukmini Devy ${ }^{2)}$ \\ Departemen Promosi Kesehatan dan Ilmu Perilaku \\ Fakultas Kesehatan Masyarakat Universitas Airlangga Surabaya \\ Email : linaagustin.k8@gmail.com
}

\begin{abstract}
Surabaya City has the highest maternal mortality ratio (MMR) in the province of East Java. That is because the lack of awareness and behavior of pregnant women for checkups in health care, so that late detection of danger signs of pregnancy. This can be prevented by behavior of pregnant women for routine antenatal care (ANC) in the health service. One Health Center in Surabaya who had the lowest levels of antenatal care visits is Wonokusumo Health Center general objective of this study was to identify and analyze the factors affecting the mother to visit antenatal care in Wonokusumo Health Center. The general objective of this study was to analyze the factors that influence the behavior of the mother to visit antenatal care in Wonokusumo Health Center. This study uses an observational study with a quantitative approach, with cross sectional design. The sampling technique used is Proportional Stratified Random Sampling with a sample of 75 respondents. Independent variables used were age, education, occupation, economic status, knowledge, attitudes, personal reference, service of health workers, while the dependent variable is the behavior of the mother's antenatal care visits. The results of this research is obtained through a questionnaire and analyzed using logistic regression. The results showed that maternal employment variables have an influence on the behavior of mothers in antenatal care visits with sig. 0,026< <0,05.
\end{abstract}

Keyword: antenatal care, behavior, mother 


\begin{abstract}
ABSTRAK
Kota Surabaya menduduki peringkat tertinggi Angka Kematian Ibu (AKI) di wilayah Provinsi Jawa Timur. Hal tersebut dikarenakan kurangnya kesadaran dan perilaku ibu hamil untuk memeriksakan kehamilannya di pelayanan kesehatan, sehingga terlambat terdeteksinya tanda bahaya kehamilan. Hal tersebut dapat dicegah dengan perilaku ibu hamil untuk rutin dalam melakukan kunjungan antenatal care (ANC) di pelayanan kesehatan. Salah satu Puskesmas di Surabaya yang memiliki tingkat kunjungan antenatal care terendah adalah Puskesmas Wonokusumo Tujuan umum dari penelitian ini adalah untuk mengidentifikasi dan menganalisis faktor yang mempengaruhi ibu untuk melakukan kunjungan antenatal care di wilayah kerja Puskesmas Wonokusumo. Tujuan umum dari penelitian ini adalah untuk menganalisis faktor yang mempengaruhi perilaku ibu untuk melakukan kunjungan antenatal care di wilayah kerja Puskesmas Wonokusumo. Penelitian ini menggunakan studi observasional dengan pendekatan kuantitatif, dengan rancangan cross sectional. Teknik sampling yang digunakan adalah Proportional Stratified Random Sampling dengan sampel 75 responden. Variabel independen yang digunakan adalah umur, pendidikan, pekerjaan, status ekonomi, pengetahuan, sikap, personal reference, pelayanan petugas kesehatan, sedangkan untuk variabel dependen adalah perilaku ibu untuk kunjungan antenatal care. Hasil penelitian ini didapat melalui kuesioner dan dianalisis menggunakan uji regresi logistic. Hasil penelitian menunjukkan bahwa variabel pekerjaan ibu mempunyai pengaruh terhadap perilaku ibu dalam melakukan kunjungan antenatal care dengan sig. $0,026<\alpha 0,05$.
\end{abstract}

\title{
Kata Kunci : antenatal care, perilaku, ibu
}

\section{PENDAHULUAN}

Indonesia merupakan salah satu negara yang sedang berkembang, dalam perkembangannya Indonesia melakukan upaya pembangunan secara Nasional. Pembangunan Nasional meliputi beberapa bidang pembangunan, salah satunya adalah pembangunan di bidang kesehatan yang tercantum dalam UU Kesehatan No. 36 tahun 2009. Masalah pembangunan di bidang kesehatan yang masih menjadi kendala hingga saat ini adalah Angka Kematian Ibu (AKI). AKI merupakan indikator pembangunan kesehatan, karena menentukan kualitas sumber daya manusia pada generasi selanjutnya (Erlina, 2012). AKI bukan hanya menjadi permasalahan di Indonesia, namun menjadi pokok bahasan di seluruh dunia, sehingga terbentuklah kesepakatan secara global yang dinamakan MDG's (Millenium Development Goals). MDG's untuk masalah kesehatan ibu terdapat pada tujuan ke-5 dan telah berakhir pada tahun 2015 namun dilanjutkan kembali dengan sebutan SDG's (Sustainability Development Goals), terdapat pada tujuan ke-3 yaitu kesehatan yang baik dan kesejahteraan.
Tahun 2015 target MDG's untuk AKI sebesar 102 per 100.000 kelahiran hidup. Sedangkan untuk SDG's dalam mencapai target untuk mengurangi AKI secara global sebesar 70 per 100.000 kelahiran hidup pada tahun 2030 (Arum, 2015).

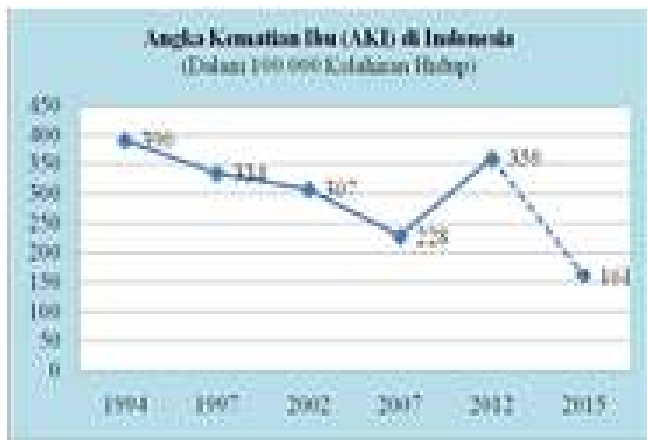

Sumber : Survei Demografi dan Kesehatan Indonesia 1994-2015

Gambar 1. Pencapaian dan Proyeksi Angka Kematian Ibu tahun 1994-2015

Berdasarkan data dari Survei Demografi dan Kesehatan Indonesia (SDKI) pada gambar 1 menunjukkan bahwa Indonesia pernah mengalami kegagalan dalam mencapai target MDG's untuk menurunkan AKI pada tahun 2012, karena di peroleh peningkatan sejumlah 36,4\% dari tahun 2007. Sedangkan estimasi yang dibuat oleh SDKI tahun 1990 hingga 2007, pada tahun 2015 AKI di Indonesia baru 
mencapai target 161 per 100.000 kelahiran hidup. Hal tersebut belum mampu mencapai target yang diinginkan MDG's yaitu 102 per 100.000 kelahiran hidup.

Data dari Profil Kesehatan Indonesia tahun 2014 menunjukkan bahwa 52,6\% penyumbang AKI terbanyak yaitu dari enam provinsi di Indonesia adalah Sumatera Utara, Banten, Jawa Barat, Jawa Tengah, Sulawesi Selatan dan Provinsi Jawa Timur. Pada tahun 2012 data dari Laporan Kematian Ibu, Provinsi Jawa Timur memiliki AKI 97,13\% dari seluruh kelahiran hidup. Sedangkan penyumbang tertinggi AKI di Provinsi Jawa Timur adalah Kota Surabaya tercatat pada tahun 2013 memiliki 49 kasus pada 41.125 kelahiran hidup Kota Surabaya menurut data Laporan Kematian Ibu pada tahun 2013.

Tingginya AKI dipengaruhi oleh beberapa faktor penyebab, penyebab secara langsung dan penyebab tidak langsung. Penyebab secara langsung adalah yang terjadi akibat komplikasi kehamilan, persalinan dan nifas. Menurut data dari Profil Kesehatan Indonesia tahun 2014 menunjukkan bahwa pada tahun 2010 pendarahan menjadi penyebab utama kematian ibu dengan persentase $35,1 \%$, namun semakin menuju ke tahun 2013 penyebab kematian ibu akibat pendarahan menurun. Sedangkan dari tahun 2010 hingga 2013 penyebab kematian ibu preeklampia atau eklamsia mengalami kenaikan terus menerus. Sedangkan menurut Laporan Tahunan Kota Surabaya tahun 2010, bahwa di Kota Surabaya pada tahun 2013 kasus eklamsia menduduki peringkat tertinggi yaitu sejumlah 14 kasus atau $28,56 \%$.

Pemerintah memiliki komitmen untuk mengatasi permasalahan kematian ibu, dengan membuat berbagai macam program pelayanan kesehatan untuk ibu hamil, salah satunya adalah dengan pemberian pemeriksaan selama kehamilan atau disebut dengan Antenatal care. Dalam pelayanan antenatal care dilakukan sekurang-kurangnya empat kali pada masa kehamilan. Capaian dari program tersebut dinilai dengan indikator cakupan K1 dan
K4. K1 atau kunjungan pertama dilakukan pada trimester pertama ketika usia kehamilan 0-12 minggu, $\mathrm{K} 4$ atau kunjungan yang dilakukan pada trimester ketiga ketika usia kehamilan 24 minggu hingga persalinan. Dalam hal ini Kota Surabaya belum mampu mencapai target, pada tahun 2012 pencapaian K1 hanya $87,40 \%$ dan K4 hanya $84,69 \%$, sedangkan target yang harus dicapai pada tahun 2012 untuk K1 sebesar $100 \%$ dan K4 sebesar $95 \%$. Kunjungan antenatal care yang rendah di Kota Surabaya dapat dipengaruhi oleh kunjungan ibu hamil di berbagai puskesmas di wilayah Kota Surabaya. Dalam hal ini Puskesmas di Kota Surabaya yang memiliki cakupan rendah adalah Puskesmas Wonokusumo memiliki data cakupan K1 dan K4 yang selalu menurun dari tahun 2011 hingga 2014. Hal tersebut dapat diakibatkan oleh beberapa kemungkinan yaitu terlambatnya ibu hamil dalam melakukan kunjungan antenatal care atau jumlah kunjungan ibu hamil untuk Antenatal care tidak sesuai dengan yang diterapkan dalam program sehingga cakupannya rendah. Hal tersebut dapat disebabkan karena prilaku dalam diri ibu untuk rutin ataupun tidak rutin dalam melakukan pemeriksaan antenatal care.

Menurut konsep teori WHO dalam Notoadmodjo tahun 2007 yaitu bahwa perilaku kesehatan seseorang itu dipengaruhi oleh pemikiran dan perasaan seseorang, adanya seseorang yg dijadikan panutan (personal references), fasilitas kesehatan yang mendukung dan budaya.

Seorang ibu hamil tidak melakukan kunjungan antenatal care secara rutin dapat dipengaruhi oleh beberapa penyebab, mungkin kurangnya pengetahuan ibu terhadap manfaat melakukan antenatal care untuk kesehatan kehamilannya, mungkin kurangnya dukungan dari orang disekitar ibu hamil untuk melakukan antenatal care, mungkin sarana pelayanan yang diberikan kurang mendukung untuk pemeriksaan antenatal care, mungkin keterbatasan biaya untuk ibu hamil dalam melakukan kunjungan antenatal care, mungkin kurangnya waktu yang tersedia bagi ibu untuk melakukan 
kunjungan antenatal care karena tidak sesuai dengan jam bekerja, sehingga membuat ibu tidak melakukan kunjungan antenatal care secara rutin.

Berdasarkan hasil data yang diperoleh dari Profil Kesehatan Kota Surabaya cakupan K1 dan K4 Puskesmas Wonokusumo pada tahun 2011 hingga 2014 beserta target pencapaiannya dapat dilihat dari tabel 1 berikut ini :

Tabel 1. Cakupan Kunjungan antenatal care di Puskesmas Wonokusumo Surabaya.

\begin{tabular}{|c|c|c|}
\hline \multirow{2}{*}{ Tahun } & \multicolumn{2}{|c|}{ Cakupan (\%) } \\
\cline { 2 - 3 } & K1 & K4 \\
\hline 2011 & 99.67 & 89.36 \\
\hline 2012 & 95.9 & 77.18 \\
\hline 2013 & 84.04 & 57.98 \\
\hline 2014 & 87.28 & 42.13 \\
\hline
\end{tabular}

Sumber : Profil Kesehatan Kota Surabaya 20112014

Tabel 2. Target Nasional Rencana Strategi Kementerian Kesehatan terhadap Kunjungan ANC

\begin{tabular}{|c|c|c|}
\hline \multirow{2}{*}{ Tahun } & \multicolumn{2}{|c|}{ Target Nasional (\%) } \\
\cline { 2 - 3 } & K1 & K4 \\
\hline 2010 & 95 & 84 \\
\hline 2011 & 96 & 88 \\
\hline 2012 & 97 & 90 \\
\hline 2013 & 98 & 93 \\
\hline 2014 & 100 & 95 \\
\hline
\end{tabular}

Sumber : Pedoman Pelayanan Antenatal Terpadu, 2010

Perbandingan diantara tabel 1 dan 2 menunjukkan bahwa Puskesmas Wonokusumo belum mampu mencapai target dan kunjungan K4 mengalami penurunan dari tahun 2011 hingga 2014.

Faktor yang menyebabkn kunjungan antenatal care di Puskesmas Wonokusumo rendah mungin karena faktor pengetahuan ibu, faktor dukungan keluarga maupun dukungan dan pelayanan petugas kesehatan, faktor pengetahuan, sikap, umur, pekerjaan, pendidikan dan status ekonomi ibu. Sehingga perlunya dilakukan kerjasama dengan melibatkan semua pihak, khususnya ibu hamil untuk mengoptimalkan kunjungan antenatal care di pelayanan kesehatan.

\section{METODE PENELITIAN}

Penelitian ini merupakan penelitian deskriptif dengan pendekatan kuantitatif yang bertujuan untuk menganalisis faktor yang mempengaruhi ibu untuk melakukan kunjungan antenatal care. Waktu pelaksanaan dalam penelitian ini termasuk dalam penelitian cross sectional study. Populasi dalam penelitian ini adalah sejumlah 278 ibu. Besar sampel menggunakan perhitungan slovin didapatkan sejumlah 75 ibu lalu dari 75 sampel tersebut dilakukan kembali pengambilan sampel dengan cara propotional stratified random sampling untuk $16 \mathrm{RW}$ yang berada di Kelurahan Wonokusumo. Kriteria inklusi berupa ibu yang memiliki bayi usia 0-5 bulan, bersedia menjadi responden, sehat saat penelitian. Lokasi penelitian dilakukan di wilayah kerja Puskesmas Wonokusumo yang berada di wilayah Kelurahan Wonokusumo Kota Surabaya, waktu penelitian dilakukan pada bulan April-Juni 2016. Variabel independennya adalah karakteristik responden (umur, pendidikan, pekerjaan, status ekonomi), pengetahuan, sikap, dukungan keluarga dan pelayanan yang diberikan oleh petugas kesehatan. Sedangkan variabel dependennya adalah perilaku ibu untuk melakukan kunjungan antenatal care.

Data primer diperoleh langsung dari responden dengan kuesioner mengenai karakteristik responden meliputi umur, pekerjaan, pendidikan dan status ekonomi, pengetahuan, sikap, seseorang yang dijadikan panutan oleh ibu untuk kunjungan antenatal care dan pelayanan yang diberikan oleh petugas kesehatan. Sedangkan data sekunder diperoleh dari Dinas Kesehatan Provinsi Jawa Timur, Dinas Kesehatan Kota Surabaya dan Puskesmas Wonokusumo Surabaya. Uji coba instrument penelitian menggunakan uji validitas dan realibilitas kepada 20 orang yang memiliki karakteristik yang sama dengan karakteristik responden. Pengisian kuesioner dilakukan sendiri oleh responden sedangkan peneliti hanya memandu dan memberikan penjelasan jika ada soal yang kurang dimengerti oleh responden. Pengolahan data hasil penelitian di lapangan dilakukan dengan menggunakan 
teknik editing, scoring, coding, tabulasi, entry, dan analysis. Teknik analisis yang dilakukan dengan bantuan komputer aplikasi SPSS karena skala minimal nominal maka uji statistic yang digunakan adalah regresi logistic. Analisa data kuantitatif untuk mengetahui frekuensinya dengan distribusi frekuensi dari seluruh variabel, tabulasi silang untuk mengetahu pengaruh antara masing-masing variabel independen dan dependen.

\section{HASIL PENELITIAN}

Berdasarkan hasil penelitian di dapatkan karakteristik responden meliputi umur, pendidikan, pekerjaan, status ekonomi ibu, pengetahuan ibu tentang antenatal care, sikap ibu tentang antenatal care, seseorang yang menjadi panutan dalam melakukan antenatal care dan pelayanan yang diberikan oleh petugas kesehatan ketika antenatal care. Secara rinci dapat dilihat di tabel 3 berikut ini :

Tabel 3. Distribusi Karakteristik Responden

\begin{tabular}{|c|c|c|}
\hline \multirow{2}{*}{$\begin{array}{c}\text { Karakteristik } \\
\text { Responden }\end{array}$} & \multicolumn{2}{|c|}{ Jumlah } \\
\hline & $\mathbf{N}$ & $\%$ \\
\hline \multicolumn{3}{|l|}{ Umur } \\
\hline $17-25$ tahun & 24 & 32,0 \\
\hline 26-45 tahun & 51 & 68,0 \\
\hline \multicolumn{3}{|l|}{ Pendidikan } \\
\hline SD & 19 & 25,3 \\
\hline SMP & 15 & 20,0 \\
\hline SMA/SMK & 33 & 44,0 \\
\hline PT & 8 & 10,7 \\
\hline \multicolumn{3}{|l|}{ Pekerjaan } \\
\hline IRT & 58 & 77,3 \\
\hline PNS & 1 & 1,3 \\
\hline Swasta & 16 & 21,3 \\
\hline \multicolumn{3}{|l|}{ Status } \\
\hline \multicolumn{3}{|l|}{ Ekonomi } \\
\hline Tinggi & 21 & 28,0 \\
\hline Rendah & 54 & 72,0 \\
\hline \multicolumn{3}{|l|}{ Pengetahuan } \\
\hline Baik & 65 & 86,7 \\
\hline Cukup & 10 & 13,3 \\
\hline \multicolumn{3}{|l|}{ Sikap } \\
\hline Tinggi & 23 & 30,7 \\
\hline Rendah & 52 & 69,3 \\
\hline \multicolumn{3}{|l|}{$\begin{array}{l}\text { Personal } \\
\text { References }\end{array}$} \\
\hline Orang Lain & 21 & 28,0 \\
\hline Keluarga & 44 & 58,7 \\
\hline
\end{tabular}

\begin{tabular}{lcc}
$\begin{array}{l}\text { Petugas } \\
\text { Kesehatan } \\
\text { Pelayanan }\end{array}$ & 10 & 13,3 \\
$\begin{array}{l}\text { Petugas } \\
\text { Kesehatan } \\
\text { Kepuasan }\end{array}$ & & \\
$\begin{array}{l}\text { Tinggi } \\
\text { Kepuasan }\end{array}$ & 27 & 36,0 \\
Rendah & 48 & 64,0 \\
\hline Sumber : data primer, 2016
\end{tabular}

Berdasarkan tabel 3 menunjukkan bahwa mayoritas responden memiliki umur 26-45 tahun yaitu sejumlah 51 ibu (68\%), mayoritas pendidikan responden adalah SMA/SMK sejumlah 33 ibu (44\%), mayoritas pekerjaan Ibu Rumah Tangga (IRT) sejumlah $58 \mathrm{ibu}(77,3 \%)$, mayoritas status ekonomi responden sejumlah $54 \mathrm{ibu}$ (73\%) memiliki status ekonomi rendah, mayoritas pegetahuan responden tentang antenatal care memiliki pengetahuan yang baik sejumlah 65 ibu (86,7\%), mayoritas sikap responden tentang antenatal care memiliki sikap yang rendah sejumlah $52 \mathrm{ibu}$ (52\%), mayoritas personal references atau seseorang yang menjadi panutan adalah dari keluarga sejumlah $44 \mathrm{ibu}(58,7 \%)$, mayoritas kepuasan responden terhadap pelayanan yang diberikan oleh petugas kesehatan memiliki kepuasan yang rendah sejumlah 48 ibu (64\%).

Tabel 4. Distribusi perilaku ibu untuk melakukan kunjungan antenatal care

\begin{tabular}{lcc}
\hline $\begin{array}{c}\text { Perilaku Ibu } \\
\text { untuk } \\
\text { Melakukan } \\
\begin{array}{c}\text { Kunjungan } \\
\text { Antenatal }\end{array}\end{array}$ & N & $\%$ \\
$\quad$ Care & & \\
\hline Rutin & 48 & 64,0 \\
Tidak Rutin & 27 & 36,0 \\
\hline Jumlah & 75 & 100,0
\end{tabular}

Berdasarkan tabel 4 menunjukkan bahwa mayoritas responden memiliki perilaku rutin untuk melakukan kunjungan antenatal care sejumlah $48 \mathrm{ibu}(64 \%)$.

Tabel 5. Distribusi karakteristik responden berdasarkan umur terhadap perilaku ibu untuk melakukan kunjungan Antenatal Care 


\begin{tabular}{lcccc}
\multirow{2}{*}{ Umur } & \multicolumn{3}{c}{ Perilaku Kunjungan ANC } \\
\cline { 2 - 5 } & \multicolumn{2}{c}{ Rutin } & \multicolumn{3}{c}{ Tidak Rutin } \\
\cline { 2 - 5 } & $\mathrm{N}$ & $\%$ & $\mathrm{~N}$ & $\%$ \\
\hline $17-25$ & 13 & 17,3 & 11 & 14,7 \\
$26-45$ & 35 & 46,7 & 16 & 21,3 \\
\hline Jumlah & 48 & 64 & 27 & 36
\end{tabular}

Berdasarkan tabel 5 menunjukkan bahwa mayoritas karakteristik berdasarkan umur ibu, yang rutin dalam melakukan kunjungan antenatal care adalah ibu yang berumur 2645 tahun.

Tabel 6. Distribusi karakteristik responden berdasarkan pendidikan terhadap perilaku ibu untuk melakukan kunjungan antenatal care

\begin{tabular}{lcccc} 
& \multicolumn{3}{c}{$\begin{array}{c}\text { Perilaku Kunjungan } \\
\text { ANC }\end{array}$} \\
\cline { 2 - 5 } Pendidikan & \multicolumn{2}{c}{ Rutin } & \multicolumn{2}{c}{ Tidak } \\
& Rutin \\
\cline { 2 - 5 } & N & $\%$ & $\mathrm{~N}$ & $\%$ \\
\hline SD & 11 & 14,7 & 8 & 10,7 \\
SMP & 9 & 12,0 & 6 & 8,0 \\
SMA/SMK & 23 & 30,7 & 10 & 13,3 \\
PT & 5 & 6,6 & 3 & 4,0 \\
\hline Jumlah & 48 & 64 & 27 & 36
\end{tabular}

Berdasarkan tabel 6 menunjukkan bahwa mayoritas karakteristik berdasarkan pendidikan ibu, yang rutin dalam melakukan kunjungan antenatal care adalah ibu yang berpendidikan SMA/SMK.

Tabel 7. Distribusi karakteristik responden berdasarkan pekerjaan terhadap perilaku ibu untuk melakukan kunjungan antenatal care

\begin{tabular}{lcccc} 
& \multicolumn{3}{c}{$\begin{array}{c}\text { Perilaku Kunjungan } \\
\text { ANC }\end{array}$} \\
\cline { 2 - 5 } Pekerjaan & \multicolumn{3}{c}{ Rutin } & \multicolumn{3}{c}{ Tidak Rutin } \\
\cline { 2 - 5 } & $\mathrm{N}$ & $\%$ & $\mathrm{~N}$ & $\%$ \\
\hline IRT & 41 & 54,7 & 17 & 22,7 \\
PNS & 0 & 0 & 1 & 1,3 \\
Swasta & 7 & 9,3 & 9 & 12,0 \\
\hline Jumlah & 48 & 64 & 27 & 36
\end{tabular}

Berdasarkan tabel 7 menunjukkan bahwa mayoritas karakteristik berdasarkan pekerjaan ibu, yang rutin dalam melakukan kunjungan antenatal care adalah ibu yang bekerja sebagai Ibu Rumah Tangga (IRT).

Tabel 8. Distribusi karakteristik responden berdasarkan status ekonomi terhadap perilaku ibu untuk melakukan kunjungan antenatal care

\begin{tabular}{lcccc} 
& \multicolumn{3}{c}{$\begin{array}{c}\text { Perilaku Kunjungan } \\
\text { ANC }\end{array}$} \\
\cline { 2 - 5 } Ekonomi & \multicolumn{3}{c}{ Rutin } & \multicolumn{3}{c}{ Tidak Rutin } \\
\cline { 2 - 5 } & $\mathrm{N}$ & $\%$ & $\mathrm{~N}$ & $\%$ \\
\hline Tinggi & 12 & 16 & 9 & 12 \\
Rendah & 36 & 48 & 18 & 24 \\
\hline Jumlah & 48 & 64 & 27 & 36
\end{tabular}

Berdasarkan tabel 8 menunjukkan bahwa mayoritas karakteristik berdasarkan ststus ekonomi ibu, yang rutin dalam melakukan kunjungan antenatal care adalah ibu yang berstatus ekonomi rendah.

Tabel 9. Distribusi pengetahuan responden terhadap perilaku ibu untuk melakukan kunjungan antenatal care

\begin{tabular}{lcccc} 
& \multicolumn{3}{c}{$\begin{array}{c}\text { Perilaku Kunjungan } \\
\text { ANC }\end{array}$} \\
\cline { 2 - 5 } Pengetahuan & \multicolumn{3}{c}{ Rutin } & \multicolumn{2}{c}{ Tidak } \\
& Rutin \\
\cline { 2 - 5 } & N & $\%$ & N & $\%$ \\
\hline Baik & 42 & 56,0 & 23 & 30,7 \\
Cukup & 6 & 8,0 & 4 & 5,3 \\
\hline Jumlah & 48 & 64 & 27 & 36
\end{tabular}

Berdasarkan tabel 9 menunjukkan bahwa mayoritas pengetahuan ibu, yang rutin dalam melakukan kunjungan antenatal care adalah ibu yang memiliki pengetahuan yang baik terhadap kunjungan antenatal care.

Tabel 10. Distribusi sikap responden terhadap perilaku ibu untuk melakukan kunjungan antenatal care

\begin{tabular}{lcccc} 
& \multicolumn{3}{c}{$\begin{array}{c}\text { Perilaku Kunjungan } \\
\text { SNC }\end{array}$} \\
\cline { 2 - 5 } & \multicolumn{3}{c}{ Rutin } & \multicolumn{3}{c}{ Tidak Rutin } \\
\cline { 2 - 5 } & $\mathrm{N}$ & $\%$ & $\mathrm{~N}$ & $\%$ \\
\hline Tinggi & 17 & 22,7 & 6 & 8 \\
Rendah & 31 & 41,3 & 21 & 28 \\
\hline Jumlah & 48 & 64 & 27 & 36
\end{tabular}

Berdasarkan tabel 10 menunjukkan bahwa mayoritas sikap ibu, yang rutin dalam melakukan kunjungan antenatal care adalah ibu yang memiliki sikap yang tinggi terhadap kunjungan antenatal care.

Tabel 11. Distribusi personal references responden terhadap perilaku ibu untuk melakukan kunjungan antenatal care 


\begin{tabular}{lcccc}
\multirow{2}{*}{$\begin{array}{l}\text { Rersonal } \\
\text { References }\end{array}$} & \multicolumn{4}{c}{$\begin{array}{c}\text { Perilaku Kunjungan } \\
\text { ANC }\end{array}$} \\
\cline { 2 - 5 } & \multicolumn{2}{c}{ Rutin } & \multicolumn{3}{c}{ Tidak Rutin } \\
\cline { 2 - 5 } & $\mathrm{N}$ & $\%$ & $\mathrm{~N}$ & $\%$ \\
\hline Orang Lain & & & & \\
Kader & 24 & 18,7 & 12 & 16,0 \\
Keluarga & & & & \\
Suami & 19 & 25,3 & 5 & 6,7 \\
Orang Tua & 8 & 10,7 & 7 & 9,3 \\
$\begin{array}{l}\text { Petugas } \\
\text { Kesehatan }\end{array}$ & & & & \\
Bidan & 7 & 9,3 & 3 & 4,0 \\
\hline Jumlah & 48 & 64 & 27 & 36
\end{tabular}

Berdasarkan tabel 11 menunjukkan bahwa mayoritas personal references ibu, yang menjadikan ibu rutin dalam melakukan kunjungan antenatal care adalah keluarga ibu yaitu suami.

Tabel 12. Distribusi kepuasan responden terhadap pelayanan petugas kesehatan dalam perilaku ibu untuk melakukan kunjungan antenatal care

\begin{tabular}{lcccc}
\multirow{2}{*}{$\begin{array}{l}\text { Pelayanan } \\
\text { Petugas }\end{array}$} & \multicolumn{3}{c}{$\begin{array}{c}\text { Perilaku Kunjungan } \\
\text { ANC }\end{array}$} \\
\cline { 2 - 5 } Kesehatan & \multicolumn{2}{c}{ Rutin } & \multicolumn{3}{c}{ Tidak Rutin } \\
\cline { 2 - 5 } & N & $\%$ & N & $\%$ \\
\hline $\begin{array}{l}\text { Kepuasan } \\
\text { Tinggi }\end{array}$ & 21 & 28 & 6 & 8 \\
$\begin{array}{l}\text { Kepuasan } \\
\text { Rendah }\end{array}$ & 27 & 36 & 21 & 28 \\
\hline Jumlah & 48 & 64 & 27 & 36
\end{tabular}

Berdasarkan tabel 12 menunjukkan bahwa mayoritas kepuasan ibu terhadap pelayanan petugas kesehatan, yang rutin dalam melakukan kunjungan antenatal care adalah ibu yang memiliki kepuasan yang rendah terhadap pelayanan petugas kesehatan selama kunjungan antenatal care.

Variabel-variabel independen tersebut di analisis menggunakan regresi logistic untuk mengetahui pengaruhnya terhadap variabel dependen yaitu perilaku ibu untuk melakukan kunjungan antenatal care.
Tabel 13. Hasil Analisis Uji Regresi Logistic

\begin{tabular}{|c|c|c|}
\hline $\begin{array}{c}\text { Variabel } \\
\text { Independen }\end{array}$ & Sig & Keterangan \\
\hline Umur & 0,393 & $\begin{array}{l}\text { Tidak } \\
\text { Berpengaruh }\end{array}$ \\
\hline Pendidikan & 0,434 & $\begin{array}{l}\text { Tidak } \\
\text { Berpengaruh }\end{array}$ \\
\hline Pekerjaan & 0,026 & Berpengaruh \\
\hline $\begin{array}{l}\text { Status } \\
\text { Ekonomi }\end{array}$ & 0,253 & $\begin{array}{l}\text { Tidak } \\
\text { Berpengaruh }\end{array}$ \\
\hline Pengetahuan & 0,941 & $\begin{array}{l}\text { Tidak } \\
\text { Berpengaruh }\end{array}$ \\
\hline Sikap & 0,129 & $\begin{array}{l}\text { Tidak } \\
\text { Berpengaruh }\end{array}$ \\
\hline $\begin{array}{l}\text { Personal } \\
\text { References }\end{array}$ & 0,709 & $\begin{array}{l}\text { Tidak } \\
\text { Berpengaruh }\end{array}$ \\
\hline $\begin{array}{l}\text { Pelayanan } \\
\text { Petugas } \\
\text { Kesehatan }\end{array}$ & 0,423 & $\begin{array}{l}\text { Tidak } \\
\text { Berpengaruh }\end{array}$ \\
\hline
\end{tabular}

Berdasarkan tabel 13 menunjukkan bahwa variabel independen yang berpengaruh adalah variabel pekerjaan ibu, karena memiliki nilai signifikan $0,026<\alpha 0,050$ dengan nilai $\operatorname{Exp}(\mathrm{B})$ atau OR (Odds Ratio) yaitu 5,191 sehingga variabel pekerjaan ibu sebagai ibu rumah tangga memiliki peluang 5,191 untuk rutin berperilaku melakukan kunjungan antenatal care dari pada ibu yang bukan bekerja sebagai ibu rumah tangga.

Pengaruh karakteristik umur ibu terhadap perilaku ibu untuk melakukan kunjungan Antenatal Care

Hasil penelitian menunjukkan bahwa dari 75 responden mayoritas berumur 26-45 tahun sejumlah $51 \mathrm{ibu}$ (68\%). Hasil analisis Uji Regresi Logistic menunjukkan nilai signifikan $=0,393>\alpha 0,050$, yang berarti tidak ada pengaruh antara umur terhadap perilaku ibu untuk melakukan kunjungan antenatal care.

Pengaruh karakteristik pendidikan ibu terhadap perilaku ibu untuk melakukan kunjungan Antenatal Care

Hasil penelitian menunjukkan bahwa dari 75 responden mayoritas memiliki pendidikan SMA/SMK sejumlah 33 ibu (44\%). Hasil analisis Uji Regresi Logistic menunjukkan nilai signifikan $=0,434>\alpha 0,050$, yang berarti tidak ada pengaruh antara pendidikan 
terhadap perilaku ibu untuk melakukan kunjungan antenatal care.

Pengaruh karakteristik pekerjaan ibu terhadap perilaku ibu untuk melakukan kunjungan Antenatal Care

Hasil penelitian menunjukkan bahwa dari 75 responden mayoritas memiliki pekerjaan sebagai ibu rumah tangga sejumlah $58 \mathrm{ibu}$ (77,3\%). Hasil analisis Uji Regresi Logistic menunjukkan nilai signifikan $=0,026<\alpha$ 0,050 , yang berarti ada pengaruh antara pekerjaan terhadap perilaku ibu untuk melakukan kunjungan antenatal care.

Pengaruh karakteristik status ekonomi ibu terhadap perilaku ibu untuk melakukan kunjungan Antenatal Care

Hasil penelitian menunjukkan bahwa dari 75 responden mayoritas memiliki status ekonomi rendah sejumlah 54 ibu (72\%). Hasil analisis Uji Regresi Logistic menunjukkan nilai signifikan $=0,253>\alpha$ 0,050 , yang berarti tidak ada pengaruh antara status ekonomi terhadap perilaku ibu untuk melakukan kunjungan antenatal care.

Pengaruh pengetahuan ibu terhadap perilaku ibu untuk melakukan kunjungan Antenatal Care

Hasil penelitian menunjukkan bahwa dari 75 responden mayoritas memiliki pengetahuan baik tentang kunjungan Antenatal Care sejumlah $65 \mathrm{ibu}(86,7 \%)$. Hasil analisis Uji Regresi Logistic menunjukkan nilai signifikan $=0,941>\alpha 0,050$, yang berarti tidak ada pengaruh antara pengetahuan terhadap perilaku ibu untuk melakukan kunjungan antenatal care.

Pengaruh sikap ibu terhadap perilaku ibu untuk melakukan kunjungan Antenatal Care

Hasil penelitian menunjukkan bahwa dari 75 responden mayoritas memiliki sikap yang rendah tentang kunjungan Antenatal Care sejumlah $52 \mathrm{ibu}(69,3 \%)$. Hasil analisis Uji Regresi Logistic menunjukkan nilai signifikan $=0,129>\alpha 0,050$, yang berarti tidak ada pengaruh antara sikap terhadap perilaku ibu untuk melakukan kunjungan antenatal care.
Pengaruh personal references ibu terhadap perilaku ibu untuk melakukan kunjungan Antenatal Care

Hasil penelitian menunjukkan bahwa dari 75 responden mayoritas memiliki personal references atau orang yang menjadi panutan untuk melakukan kunjungan antenatal care adalah keluarga sejumlah 44 ibu (58,7\%). Hasil analisis Uji Regresi Logistic menunjukkan nilai signifikan $=0,709>\alpha$ 0,050 , yang berarti tidak ada pengaruh antara personal references atau seseorang sebagai panutan ibu untuk melakukan kunjungan antenatal care.

Pengaruh Pelayanan Petugas Kesehatan ibu terhadap perilaku ibu untuk melakukan kunjungan Antenatal Care

Hasil penelitian menunjukkan bahwa dari 75 responden mayoritas memiliki kepuasan rendah terhadap pelayanan yang diberikan oleh petugas kesehatan ketika Antenatal Care sejumlah 48 ibu (64\%). Hasil analisis Uji Regresi Logistic menunjukkan nilai signifikan $=0,423>\alpha 0,050$, yang berarti tidak ada pengaruh antara kepuasan terhadap pelayanan yang diberikan oleh petugas kesehatan ketika Antenatal Care terhadap perilaku ibu untuk melakukan kunjungan antenatal care.

\section{PEMBAHASAN}

Pengaruh karakteristik umur ibu terhadap perilaku ibu untuk melakukan kunjungan Antenatal Care

Analisis data menggunakan uji regresi logistic diperoleh signifikan $=0,393>\alpha$ 0,050 yang berarti tidak ada pengaruh antara umur ibu terhadap perilaku ibu untuk melakukan kunjungan Antenatal Care. Hal ini sesuai dengan penelitian Pongsibidang (2013).

Hasil tabulasi silang pada tabel 5 menunjukkan bahwa ibu yang rutin dalam melakukan kunjungan antenatal care. adalah ibu yang berumur 26-45 tahun. Menurut Adawiyah (2013) umur merupakan variabel yang tidak bisa di modifikasi. Umur dapat mempengaruhi proses reproduksi, umur 2035 tahun merupakan umur yang aman untuk masa reproduksi dan hamil. Sejak umur 20 tahun organ reproduksi telah matang dan 
siap untuk menerima kehamilan. Seorang ibu yang siap hamil memerlukan kesiapan dan kematangan psikologis, perlunya kesabaran dan pemahaman tentang kebutuhan dirinya selama kehamilan untuk keselamatan dalam proses kehamilannya. Sehingga umur 26-45 adalah tergolong umur yang masih mudah dalam menerima informasi yang masuk.

\section{Pengaruh karakteristik pendidikan ibu terhadap perilaku ibu untuk melakukan kunjungan Antenatal Care}

Analisis data menggunakan uji regresi logistic diperoleh signifikan $=0,434>\alpha$ 0,050 yang berarti tidak ada pengaruh antara pendidikan ibu terhadap perilaku ibu untuk melakukan kunjungan Antenatal Care. Hal ini sesuai dengan penelitian Sheilla (2014). Hasil tabulasi silang pada tabel 6 menunjukkan bahwa ibu yang rutin dalam melakukan kunjungan antenatal care. adalah ibu dengan tingkat pendidikan SMA/SMK. Menurut Ramasamy (2013) tingkat pendidikan yang tinggi dapat membuat ibu memperoleh informasi lebih tentang antenatal care seperti pada radio, televisi maupun internet. Hal ini menunjukkan bahwa, meskipun mayoritas responden berpendidikan SMA/SMK bukan berarti responden memiliki pengetahuan yang baik tentang antenatal care.

Pengaruh karakteristik pekerjaan ibu terhadap perilaku ibu untuk melakukan kunjungan Antenatal Care

Analisis data menggunakan uji regresi logistic diperoleh signifikan $=0,026<\alpha$ 0,050 yang berarti ada pengaruh antara pekerjaan ibu terhadap perilaku ibu untuk melakukan kunjungan antenatal care. Hal ini sesuai dengan penelitian Nurlaelah (2014) bahwa ada pengaruh jenis pekerjaan ibu terhadap perilakunya untuk melakukan kunjungan antenatal care.

Hasil tabulasi silang pada tabel 7 menunjukkan bahwa ibu yang rutin dalam melakukan kunjungan antenatal care. adalah ibu dengan pekerjaan sebagai Ibu Rumah Tangga (IRT). Menurut Umar (2014) seorang ibu yang bekerja di sektor formal lebih memiliki informasi yang lebih baik tentang kunjungan antenatal care dari pada ibu yang tidak bekerja, informasitersebut dapat diperoleh melalui bebagai media. Selain itu ibu yang bekerja di sektor formal memiliki penghasilan sendiri sehingga mampu menambah perekonomian keluarga dan mampu memilih dan menggunakan fasilitas kesehatan yang di inginkan. Tetapi disisi lain ibu yang bekerja di sektor formal memiliki waktu yang terbatas untuk melakukan kunjungan antenatal care karena telah memiliki kontrak kerja dengan instansi tempat ibu bekerja dari pada ibu yang tidak bekerja atau ibu rumah tangga. Hal ini menunjukkan bahwa ibu yang tidak bekerja berpengaruh terhadap rutinnya melakukan kunjungan antenatal care, karena ibu yang tidak bekerja memiliki waktu yang cukup banyak di rumah dan tidak terikat kontrak waktu dengan instansi manapun, sehingga ibu yang tidak bekerja akan melakukan kunjungan antenatal care secara rutin.

Pengaruh karakteristik status ekonomi ibu terhadap perilaku ibu untuk melakukan kunjungan Antenatal Care

Analisis data menggunakan uji regresi logistic diperoleh signifikan $=0,253>\alpha$ 0,050 yang berarti tidak ada pengaruh antara status ekonomi ibu terhadap perilaku ibu untuk melakukan kunjungan antenatal care. Hal ini tidak sesuai dengan penelitian Astuti (2014) bahwa ada pengaruh status ekonomi terhadap perilaku ibu untuk kunjungan antenatal care.

Hasil tabulasi silang pada tabel 8 menunjukkan bahwa ibu yang rutin dalam melakukan kunjungan antenatal care. adalah ibu dengan status ekonomi rendah. Menurut Widian (2008) dalam Astuti (2014) bahwa ekonomi menjadi faktor penentu untuk ibu dalam proses kehamilan yang sehat, ibu dengan status ekonomi yang cukup memiliki kuasa untuk melakukan pemeriksaan kehamilan secara ruin, merencanakan persalinannya ke tenaga kesehatan, dan dapat melakukan persiapan yang lain secara matang. Sebaliknya jika ibu berasal dari keluarga yang kurang maka mereka akan mempertimbangkan biaya yang akan dikeluarkan untuk kunjungan antenatal care. Namun hal ini tidak berpengaruh terhadap kesehatan kehamilan ibu, karena pada masa ini, seluruh pemeriksaan 
kehamilan atau antenatal care tidak dipungut biaya untuk pemeriksaan khususnya di pelayanan kesehatan puskesmas.

\section{Pengaruh pengetahuan ibu terhadap perilaku ibu untuk melakukan kunjungan Antenatal Care}

Analisis data menggunakan uji regresi logistic diperoleh signifikan $=0,941>\alpha$ 0,050 yang berarti tidak ada pengaruh antara pengetahuan ibu terhadap perilaku ibu untuk melakukan kunjungan antenatal care. Hal ini sesuai dengan penelitian Vitriyani (2012) bahwa ada pengaruh tingkat pengetahuan ibu terhadap perilaku ibu untuk kunjungan antenatal care.

Hasil tabulasi silang pada tabel 9 menunjukkan bahwa ibu yang rutin dalam melakukan kunjungan antenatal care. adalah ibu dengan tingkat pengetahuan tinggi. Menurut Notoadmodjo (2012) bahwa pengetahuan adalah hasil dari penginderaan manusia terhadap objek, proses penginderaan tersebut dipengaruhi oleh intensitas perhatian dan persepsi terhadap objek. Sebagian besar pengetahuan diperoleh melalui indera telinga berupa pendengaran dan indera mata berupa penglihatan. Hal ini menunjukkan bahwa sebagian ibu memiliki pengetahuan yang cukup baik tentang kunjugan antenatal care bukan berarti berpengaruh terhadap perilakunya. Menurut teori Lawrence Green tahun 1980 dalam Notoadmodjo (2007) bahwa terbentuknya perilaku seseorang itu terdapat 3 faktor yaitu predisposing factor (pengetahuan, sikap, kepercayaan, keyakinan), enabling factor yang terwujud dalam lingkungan fisik, tersedia atau tidak tersedianya fasilitas kesehatan, dan yang terakhir adalah reinforcing factor yang terwujud dalam sikap dan perilaku orang disekitar. Sehingga walaupun memiliki pengetahuan yang cukup baik, namun tidak didukung oleh faktor yang lain maka perilaku ibu dalam kunjungan antenatal care juga tidak terbentuk.

Pengaruh sikap ibu terhadap perilaku ibu untuk melakukan kunjungan Antenatal Care
Analisis data menggunakan uji regresi logistic diperoleh signifikan $=0,129>\alpha$ 0,050 yang berarti tidak ada pengaruh antara sikap ibu terhadap perilaku ibu untuk melakukan kunjungan antenatal care. Hal ini sesuai dengan penelitian Asihani (2010) bahwa sikap berpengaruh tidak nyata terhadap kunjungan antenatal care.

Hasil tabulasi silang pada tabel 10 menunjukkan bahwa ibu yang rutin dalam melakukan kunjungan antenatal care. adalah ibu dengan sikap yang rendah. Menurut Notoadmodjo (2007) bahwa sikap bukan merupakan tingkah laku atau perilaku, sikap merupakan predisposisi tindakan suatu perilaku, sehingga sikap merupakan reaksi tertutup.

\section{Pengaruh personal references ibu terhadap perilaku ibu untuk melakukan kunjungan Antenatal Care}

Analisis data menggunakan uji regresi logistic diperoleh signifikan $=0,709>\alpha$ 0,050 yang berarti tidak ada pengaruh antara personal references ibu terhadap perilaku ibu untuk melakukan kunjungan antenatal care. Hal ini sesuai dengan penelitian Siringo (2011) bahwa tidak ada korelasi yang bermakna antara keluarga dengan kunjungan antenatal care.

Hasil tabulasi silang pada tabel 11 menunjukkan bahwa ibu yang rutin dalam melakukan kunjungan antenatal care adalah ibu dengan personal reference keluarga khususnya suami. Menurt Manuaba (2006) motivasi keluarga merupakan suatu dukungan psikososial yang mampu memberikan kekuatan emosional kepada ibu, sehingga dalam hal ini bahwa keluarga dapat dijadikan panutan untuk ibu dalam melakukan kunjungan antenatal care. Hal ini menunjukkan bahwa ibu memilih personal reference keluarga khususnya suami belum tentu mempengaruhi perilaku ibu, karena disebabkan oleh pengetahuan suami yang kurang terhadap pentingnya pelayanan antenatal care, dan waktu yang dimiliki suami terbatas sehingga tidak memiliki cukup waktu untuk menemani ibu memeriksakan kehamilannya. 
Pengaruh Pelayanan Petugas Kesehatan ibu terhadap perilaku ibu untuk melakukan kunjungan Antenatal Care

Analisis data menggunakan uji regresi logistic diperoleh signifikan $=0,423>\alpha$ 0,050 yang berarti tidak ada pengaruh antara pelayanan petugas kesehatan terhadap perilaku ibu untuk melakukan kunjungan antenatal care. Hal ini tidak sesuai dengan penelitian Nida'a (2014) bahwa adanya pengaruh sikap pelayanan petugas kesehatan dengan pemanfaatan kunjungan antenatal care.

Hasil tabulasi silang pada tabel 12 menunjukkan bahwa ibu yang rutin dalam melakukan kunjungan antenatal care adalah ibu dengan kepuasan rendah terhadap pelayanan petugas kesehatan. Menurut Nida'a (2014) petugas yang memberikan kesan baik terhadap ibu hamil akan menimbulkan kepuasan dan membuatnya merasa percaya diri untuk tetap memeriksakan kesehatannya, hal ini akan memberikan dampak pada keinginan ibu untuk melanjutkan kunjungan antenatal care di pelayanan kesehatan. Dalam teori Lawrence Green (1980) bahwa terbentuknya perilaku ada 3 faktor, salah satunya adalah reinforcing factor yaitu faktor yang terwujud dalam sikap dan perilaku petugas kesehatan. Hal ini menunjukkan bahwa walaupun ibu dengan tingkat kepuasan rendah terhadap pelayanan petugas kesehatan yang diberikan tidak mempengaruhi terhadap kerutinan

\section{SIMPULAN DAN SARAN}

Tidak ada pengaruh signifikan (sig. $=0,393$ ) antara umur ibu dengan perilaku dalam kunjungan antenatal care. Tidak ada pengaruh signifikan (sig. $=0,434)$ antara pendidikan $\mathrm{ibu}$ dengan perilaku dalam kunjungan antenatal care. Ada pengaruh signifikan (sig.= 0,026) dengan $\operatorname{Exp}(B)$ 5,191 antara pekerjaan ibu dengan perilaku dalam kunjungan antenatal care. Tidak ada pengaruh signifikan (sig. $=0,253$ ) antara status ekonomi ibu dengan perilaku dalam kunjungan antenatal care. Tidak ada pengaruh signifikan (sig. $=0,941$ ) antara pengetahuan $\mathrm{ibu}$ dengan perilaku dalam kunjungan antenatal care. Tidak ada pengaruh signifikan (sig.= 0,129) antara sikap ibu dengan perilaku dalam kunjungan antenatal care. Tidak ada pengaruh signifikan (sig. $=0,709$ ) antara personal references ibu dengan perilaku dalam kunjungan antenatal care. Tidak ada pengaruh signifikan (sig. $=0,473)$ antara pelayanan petugas kesehatan ibu dengan perilaku dalam kunjungan antenatal care.

\section{SARAN}

Diharapkan kepada ibu hamil agar meluangkan waktunya untuk melakukan kunjungan antenatal care khususnya untuk ibu yang bekerja secara formal, yang tidak memiliki cukup waktu untuk memeriksakan kehamilannya. Walupun bekerja secara formal ibu hamil dapat melakukan kunjungan antenatal care setelah pulang bekerja di pelayanan kesehatan yang tersedia contohnya di rumah sakit, praktek bidan atau dokter dan klinik kesehatan.

Kepada Puskesmas Wonokusumo dan pelayanan kesehatan lainnya untuk meningkatkan pelayanan kesehatan yang diberikan khususnya tentang keramahan pelayanan petugas kesehatan. Meningkatkan penyuluhan tentang pentingnya kunjungan antenatal care dan perawatan kehamilan untuk pasangan usia subur melibatkan bidan maupun kader-kader posyandu.

Perlu diadakan penelitian lebih lanjut terhadap faktor-faktor yang berhubungan dengan kunjungan antenatal care dengan variabel-variabel yang belum diteliti pada penelitian ini.

\section{DAFTAR PUSTAKA}

Adawiyah, R., 2013. Faktor- Faktor Yang Berhubungan Dengan Kunjungan Antenatal Care Di Puskesmas Mongolato Kecamatan Telaga Kabupaten Gorontalo Tahun 2013. Universitas Negeri Gorontalo, [ejournal]. Tersedia di:https://www.google.co.id/url?sa=t $\& \mathrm{rct}=\mathrm{j} \& \mathrm{q}=\&$ esrc $=\mathrm{s} \&$ source $=$ web $\& \mathrm{c}$ $\mathrm{d}=1 \& \mathrm{cad}=$ rja\&uact $=8 \& \mathrm{ved}=0 \mathrm{ahUK}$ EwiJ_sqA0_DNAhUPSo8KHW1fA_ cQFggaMAA_\&url=http $\% 3 \mathrm{~A} \% 2 \mathrm{~F} \% 2$ Fkim.ung.ac.id\%2Findex.php\%2FKI MFIKK\%2Farticle\%2Fdownload\%2 F2837\%2F2813\&usg=AFQjCNG6i6 
3RpSm9zTKw_VXIG9iNXLwqJA\& sig2 $=$ Sv-8mdNnO6FI3yOdhnfsQ\&bvm=bv.126993452,d.c2I [25 Juni 2016].

Arista, D.S., 2014. Pengaruh Karakteristik Demografi, Covert Behavior, dan Akses Pelayanan Kesehatan Ibu Hamil Terhadap Kunjungan Antenatal Care di Wilayah Kerja Puskesmas Manding Sumenep. Skripsi. Universitas Airlangga.

Asihani, D., 2010. Hubungan Antara Persepsi Dan Sikap Ibu Hamil Tentang Antenatal Care Dengan Kunjungan Pemeriksaan Kehamilan Di Rumah Bersalin Permata Bunda Sragen. Tesis. Universitas Sebelas Maret. Tersedia di: file://C:/Users/Lina/Downloads/dwi \%20asihani\%20(1).pdf [27 Juni 2016].

Astuti, A.E., 2014. Hubungan Tingkat Pengetahuan Dan Status Ekonomi Ibu Hamil Dengan Kunjungan K4 Di Wilayah Kerja Puskesmas Duren Kabupaten Semarang. Kebidanan Ngudi Waluyo. [e-journal]. Tersedia di:

http://perpusnwu.web.id/karyailmiah/ documents/3662.pdf [25 Juni 2016].

Atmawikarta, Arum. 2015. Perkembangan Terkini MDGs dan Pembangunan Berkelanjutan $2030 \quad$ (SDGs). Surabaya; Kuliah Umum FKM UNAIR: 80-85.

Depkes RI. 2009. Profil Kesehatan Indonesia. Jakarta; Departemen Kesehatan

Republik Indonesia.

Depkes RI. 2010. Profil Kesehatan Indonesia. Jakarta; Departemen Kesehatan

Republik Indonesia.

Dinkes. Prov.Jatim., 2013. Profil Kesehatan Provinsi Jawa Timur Tahun 2012. Surabaya; Kep. Dinkes. 8-123.

Dinkes. Kota Surabaya. 2013. Profil PKM Wonokusumo.Tersedia di http://dinkes.surabaya.go.id/portal/in dex.php/puskesmas/pkmwonokusumo/\# [6 Juni 2016].
Erlina, R., Larasati, TA., Kurniawan, B. 2013. Faktor-Faktor Yang Mempengaruhi Ibu Hamil Terhadap Kunjungan Pemeriksaan Kehamilan Di Puskesmas Rawat Inap Panjang Bandar Lampung. Medical Journal of Lampung University, Vol.2 No. 4: 29-34.

Kemenkes. R.I., 2009. Pedoman Pemantauan Wilayah Setempat Kesehatan Ibu dan Anak (PWS-KIA). Jakarta; Ditjen Kesmas: 7-8.

Kemenkes. R.I., 2010. Pedoman Pelayanan Antenatal Terpadu. Jakarta; Ditjen Kesmas: 12-19.

Kemenkes. R.I., 2013. Rencana Aksi Percepatan penurunan Angka Kematian Ibu di Indonesia. Jakarta; Ditjen Gizi dan KIA: 1-4.

Kemenkes. R.I., 2015. Profil Kesehatan Indonesai 2014. Jakarta; Sekjen Kemenkes: 86-90.

Manuaba. 2006. Buku Ajar Patologi Obstetri. Jakarta: EGC.

Nida'a, A., 2014. Faktor Yang Berhubungan Dengan Pemanfaatan Pelayanan Antenatal Care Masyarakat Pesisir Di Wilayah Kerja Puskesmas Sanrobone Kab.Takalar Tahun 2014. Skripsi. Universitas Hasanuddin. Tersedia di: http://repository.unhas.ac.id:4001/dig ilib/files/disk1/324/--ainunnidaa16180-1-15-ainun ).pdf [27 Juni 2016].

Notoatmodjo, Soekidjo. 2007. Promosi Kesehatan dan Ilmu Perilaku. Jakarta. Rineka Cipta: 177-193.

Notoatmodjo, Soekidjo. 2012. Perilaku Kesehatan. Jakarta. Rineka Cipta: 9397.

Nurlaelah, 2014. Faktor Yang Berhubungan Dengan Kunjungan Antenatal Care Di Wilayah Kerja Puskesmas Dungkait Kabupaten Mamuju. Universitas Hasanuddin, [e-journal]. Tersedia di: http://repository.unhas.ac.id/bitstrea $\mathrm{m} / \mathrm{handle} / 123456789 / 11503 /$ NURLA ELAH\%20K11112620.pdf?sequence $=1$ [25 Juni 2016]. 
Ramasamy, A., 2013. Hubungan Tingkat Pendidikan dengan Tingkat Pengetahuan Tentang Antenatal Care dalam Kalangan Ibu Usia Subur. Universitas Sumatera Utara, [ejournal] Vol.1 No.1. Tersedia di: http://download.portalgaruda.org/arti cle.php? article $=51337 \& \mathrm{val}=4098$ [diakses tanggal 27 Juni 2016].

Siringo, A., 2011. Pengetahuan Ibu Hamil Dan Motivasi Keluarga Dalam Pelaksanaan Antenatal Care Di Puskesmas Ujung Batu Riau. Universitas Sumatera Utara. [ejournal]. Tersedia di: http://jurnal.usu.ac.id/index.php/jkh/a rticle/view/317 [25 Juni 2016].

Umar, N., 2014. Faktor Determinan Pemanfaatan Pelayanan Antenatal Di Wilayah Kerja Puskesmas Batua Kecamatan Manggala Kota Makassar. Universitas Hasanuddin. [e-journal]. Tersedia di: http://repository.unhas.ac.id/bitstrea $\mathrm{m} /$ handle/123456789/9405/Nilasari\% 20Umar\%20K11110257.pdf?sequen ce $=1$ [25 Juni 2016].

Undang-Undang Republik Indonesia Nomor 36 Tahun 2009 Tentang Kesehatan.

Vitriyani, E., 2012. Faktor-Faktor Yang Berhubungan Dengan Pemeriksaan Antenatal Care (Anc) K1 Ibu Hamil Di Kecamatan Polokarto Kabupaten Sukoharjo. Skripsi. Universitas Muhammadiyah Surakarta. Tersedia di: http://eprints.ums.ac.id/22065/17/02. _NASKAH_PUBLIKASI.pdf Juni 2016]. 
JURNAL ILMIAH KESEHATAN MEDIAHUSADA | VOLUME 06/NOMOR 01/MARET 2017 